Article

\title{
The Role of International Entrepreneurial Orientation in Successful Internationalization from the Network Capability Perspective
}

\author{
Junghyun Yoon ${ }^{1}$, Ki Keun Kim ${ }^{2, *}$ and Alisher Tohirovich Dedahanov ${ }^{3, *}$ \\ 1 College of Management \& Economics, Dongguk University-Gyeongju, Gyeongju-si 38066, Korea; \\ jyoon071121@naver.com \\ 2 Department of Industry Business Administration, Gumi University, Gumi-si 39213, Korea \\ 3 School of Business, Yeungnam University, Gyeongsan-si 38541, Korea \\ * Correspondence: 22devil@hanmail.net (K.K.K.); sarbon22513@ynu.ac.kr (A.T.D.); \\ Tel.: +82-10-2978-2012 (A.T.D.)
}

Received: 4 April 2018; Accepted: 14 May 2018; Published: 24 May 2018

check for updates

\begin{abstract}
Purpose/Research Question: In general, networks have played a role in improving innovation, and early-stage companies adopt an entrepreneurial orientation to secure competitiveness. In other words, the companies would like to penetrate global markets due to the CEO's international entrepreneurial orientation. In addition, by utilizing their networks, the companies would like to improve their international performance. Relatively few studies have been devoted to investigating the empirical relationships between entrepreneurial orientation, networks, and international performance. In particular, technology-based firms are one of the best samples. Therefore, this study aims to explore the characteristics of the firms and then investigate comprehensively and empirically the relationships between international entrepreneurial orientation, networks, and international performance, based on data from technology-based firms in South Korea. Design/Methodology/Approach: The study analyzes data from technology-based small and medium-sized enterprises (SMEs) using structural equation modeling (SEM). It assumes that networks will play a moderating role in the relationships between international entrepreneurial orientation and international performance. We carried out the survey after conducting interviews with CEOs of SMEs. Findings/Results: International entrepreneurial orientation has a significant effect on international performance. Moreover, the stronger the networks that SMEs have with other stakeholders such as universities, industries, and technoparks, the higher their international performance. With stronger networks, tech-based SMEs have easier access to useful technologies and hence better international performance. Research Limitations/Implications: There are some limitations to this study. First of all, the study relied heavily on quantitative methods, such as surveys. This approach is inadequate for considering individuals' in-depth opinions. Therefore, future research utilizing both qualitative and quantitative measures needs to be carried out. Second, this study has some academic limitations. In fact, this study considered restricted factors regarding innovation and networks; thus it is necessary to evaluate other variables such as environmental factors (e.g., regulations or support policies) that might be significantly associated with networks and innovation hereafter. Finally, due to the fact that this study was focused on SMEs, it is difficult to generalize the above results. However, this study implies that stronger network ties improve international performance, thus SMEs must establish and reinforce networks to improve the performance.
\end{abstract}

Keywords: international entrepreneurial orientation; networks; international performance; technology-based small and medium-sized enterprises 


\section{Introduction}

As globalization and economic regionalism spread rapidly, international competition between firms and/or nations has been considered an inevitable activity to improve competitiveness and performance [1]. Moreover, the decrease of trade barriers and the technological advances of electronic communication and the Internet lead firms to internationalization. It is important for both small and medium-sized enterprises (SMEs) and large companies to enter international markets. In other words, internationalization is a strategic choice for them. The role of SMEs in international markets has gradually become more important, as well as having expanded [2]. As a result of the growing importance of SMEs in global markets, both entrepreneurs and scholars are interested in the internationalization of SMEs [3]. In particular, much attention has been focused on the relationships between factors to improve competitiveness or performance [4,5].

Although SMEs would like to become more international, based on their core competencies such as their technology capabilities, in order to survive and grow in the era of strong global competition, it is very difficult to successfully enter international markets, because they have limitations such as a lack of resources compared to the large enterprises [6,7]. As a result, SMEs would like to establish useful networks to overcome these limitations. In particular, networks among firms and higher education and research institutions such as technoparks has played a pivotal role in the successful internationalization of SMEs. Some prior studies (e.g., [8]) have taken into account networks; however, they did not suggest concrete network examples, such as the above-mentioned networks (networks between firms and higher education and research institutions, such as technoparks). Therefore, this study would like to make up for the limitations of prior studies by considering clearer network examples.

Whilst exploratory studies and case studies on firm internationalization have been carried out diversely, relatively little empirical research has been conducted on internationalization [9]. Furthermore, prior studies on internationalization have not only focused on specific targets such as IT and the electronic industries [10], but also dealt with the internationalization process of unique companies such as 'born-globals' and 'international new ventures (INVs)' [11]. In spite of the fact that the previous studies have contributed to developing and establishing a theoretical system regarding the internationalization process, they do not significantly affect the development of empirical studies. This implies that prior studies might not consider a comprehensive study on internationalization or various measurement items with regard to the internationalization, even though they have revealed that internationalization can be decided by some determinants such as government policies. Recently, a large number of studies regarding internationalization have been carried out. However, from a competence or capability point of view, the studies investigating internationalization are still insufficient. In particular, as far as we know, there is no study taking into account both the entrepreneurial orientation and the capability point of view as variables able to determine internationalization. Therefore, this study aims to implement an empirical study by establishing a comprehensive model considering various determinants (e.g., entrepreneurial orientation and capabilities) of internationalization, based on small and medium-sized exporting companies. This comprehensive model was designed in order to overcome and complement the above-mentioned limits; prior studies have not considered various factors that can determine internationalization, having focused on a specific type of companies such as ventures or born-globals. Relatively little academic attention has been paid to examining internationalization from the capability perspective. Based on the comprehensive model, this study would like to contribute to the theoretical development of determinants for the internationalization of exporting SMEs, as well as to help both working-group officials who want to penetrate international markets and policy makers who want to support exporting SMEs, by establishing successful international strategies. 


\section{Literature Review and Hypotheses}

\subsection{Internationalization}

Prior studies on internationalization can be classified into three main categories, namely exploratory studies [12], case studies [13], and empirical studies [3]. Besides this, there are studies on the international process of born-globals that seek internationalization inherently [11]. Although the above studies have contributed to establishing a theoretical system, their contribution is not sufficient in terms of empirical studies. To be specific, most of the studies on internationalization have focused on the rationales of internationalization [14,15], the entrance strategies of internationalization [16], and the internationalization process [2,17]. Nevertheless, these studies did not consider a variety of indicators to measure internationalization, as well as were not having been carried out from a comprehensive point of view. They are just focused on a few determinants of internationalization. Based on prior studies, the determinants of internationalization can be categorized into three main factors; first, entrepreneurial characteristics such as the CEO's international experience, global orientation, entrepreneurial orientation and network capability [8]; second, technological characteristics such as research and development (R\&D), technical skills and know-how [18]; and third, environmental characteristics such as industrial environment, international market environment, and competition abroad and/or the domestic market [16]. In particular, based on interviews with staff, Panagariya [19] argued that corporate capability is the critical factor for successful internationalization. Furthermore, through an empirical analysis, Hsu and Wang [20] found that the stronger capabilities firms have, the faster their internationalization. Notwithstanding that, there is no study reflecting two or more determinants of internationalization at the same time, that is, no study takes into account distinguished factor groups (e.g., independent variable and mediator and/or independent variable and moderator) together.

\subsection{Hypotheses}

In order to overcome and complement the limitations of prior studies (e.g., limited research target, limited determinants and insufficient study in terms of firm capability), this study constructed a comprehensive model that considers various determinants of successful internationalization including entrepreneurial orientation and capability, etc., based on exporting SMEs in South Korea.

\subsubsection{International Entrepreneurial Orientation and Network Capability}

Many scholars (e.g., [21]) have long defined international entrepreneurial orientation from the internationalization vision and active and enthusiastic attitude perspective. International entrepreneurial orientation has a close relationship with a firm's capabilities [6]. In general, international entrepreneurial orientation tends to be connected to the personal characteristics of the men/women who would like to found a new company or begin a new business. However, the international entrepreneurial orientation caused by firm capabilities not is limited to personal ability, but is a feature that is inherent to the whole organization. Therefore, the significant influence of international entrepreneurial orientation exists between organizational resource and operational skills [22]. In other words, international entrepreneurial orientation is a different definition from the competencies that firms have. For instance, Teece [22] emphasized entrepreneurial orientation, stating that the stronger the entrepreneurial orientation, the greater the organizational capabilities. That is to say that entrepreneurial orientation is significantly correlated to firm capabilities, with the prerequisite that the resources in an organization can be integrated, adjusted, and relocated more effectively depending on entrepreneurial characteristics (e.g., international entrepreneurial orientation, different experience, etc.). According to entrepreneurs, the efficiency and the utilization of resources can be expanded, enhancing the firm's capabilities.

Defining international entrepreneurial orientation as "the discovery, enactment, evaluation, and exploitation of opportunities-across national borders-to create future goods and services", 
McDougall et al. [6] and Oviatt and McDougall [2] argued that SMEs that would like to enter into global markets have an international entrepreneurial orientation and capabilities. In addition, there are four constructs in international entrepreneurial orientation, namely the internationalization vision [23], proactive behavior [2], and innovative and risk-taking behavior for successful internationalization [24]. Furthermore, Hitt and Ireland [25] designated management capability, production and operation management capability, marketing capability, and technological capability as moderators of international entrepreneurial orientation. Based on their argument, Zou, Liu and Ghauri [26] and $\mathrm{Xu}$, Carter, Taute and Dishman [27] emphasized that in order to have and improve these capabilities, stronger international entrepreneurial orientation has to be demonstrated. Through an empirical study, Knight [28] found that there was a significant correlation between marketing competence and entrepreneurial orientation. This significant correlation was found due to the characteristics of international entrepreneurial orientation [29]. In other words, international entrepreneurial orientation plays a pivotal role in maintaining and improving a firm's marketing competence, as a firm with an international entrepreneurial orientation is willing to look for an opportunity to enter into a new market as well as reacting sensitively to customers' needs [24]. In line with this thinking, Yoon and Kim [30] confirmed that entrepreneurial orientation affects organizational performance throughout organizational capacities rather than affecting it directly. That is to say, international entrepreneurial orientation is not only an antecedent of internationalization, but also of organizational core competencies (e.g., network competency, marketing competency, and technological competency). Lastly, as one of the most critical factors regarding organizational capability, network capability depends on the entrepreneurial orientation [31]. The more risk-taking, proactive and innovative that a company is, the greater their capacities [32,33]. In summary, there is a significant positive correlation between international entrepreneurial orientation and organizational capabilities [34]. Therefore, this study has developed the following hypotheses to explore the empirical relationships between the aforementioned.

Hypothesis 1. International entrepreneurial orientation has significant positive effects on network capability.

Hypothesis 1-1. Innovativeness has a significant positive effect on network capability.

Hypothesis 1-2. Proactiveness has a significant positive effect on network capability.

Hypothesis 1-3. Risk-taking has a significant positive effect on network capability.

\subsubsection{International Entrepreneurial Orientation, Network Capability, and International Performance}

Examining the relationship between entrepreneurial orientation and performance, Zahra et al. [35] found that entrepreneurial orientation can improve competitive advantage, improving the learning and knowledge of companies. Yiu, Lau and Bruton [36] designated innovation, venture and strategic choice as constructs of entrepreneurial orientation, and hence analyzed the relationships between the constructs and the internationalization. As a result, they identified that entrepreneurial orientation plays an important role in achieving internationalization, and especially that risk-taking is the greatest determinant of internationalization. With respect to the reason why entrepreneurial orientation has a significant positive effect on internationalization, Porter [37] noted that if early stage SMEs would like to enter into a global market, they will face to the strict entry barriers, needing to establish a network with external stakehlders. Moreover, Florida [38] found out that entrepreneurial orientation makes venture companies take risks and thus penetrate into international markets to sell their innovative products. As venture companies can collect useful information and knowledge regarding global markets through their experience, they can improve their international performance. Knight [28] also mentioned that entrepreneurial orientation is crucial to respond to the rapidly changing business environment, arguing that a leading marketing strategy based on entrepreneurial orientation promotes 
better international performance, that is, CEOs, with a stronger entrepreneurial orientation tend to enhance core competencies, thereby improving international performance [39]. On the other hand, Etemad [40] revealed that among the key factors influencing international performance, the most significant factor is the CEOs' entrepreneurial orientation. They emphasized that international performance significantly depends on the sub-constructs of entrepreneurial orientation (i.e., innovation, proactiveness, and risk-taking). As discussed in the previous studies, firms, including SMEs with a greater entrepreneurial orientation, show an aggressive attitude in seeking new opportunities to enter into international markets, as well as to establish and operate departments that actively carry out the internationalization activities. This entrepreneurial orientation plays a pivotal role in overcoming external environment changes and improving international performance throughout organizational capabilities such as network capabilities [41]. In particular, the entrepreneurial orientation in exporting SMEs that have insufficient resources and difficulties entering a new global market, functions as the most essential variable in that they have to carry out creative activities and to utilize internal resources effectively to develop new business opportunities. Therefore, the entrepreneurial orientation, composed of risk-taking, innovativeness, and proactiveness, has a positive effect on performance [42]. Conducting an empirical study on entrepreneurial orientation, $\mathrm{Zhou}, \mathrm{Wu}$, and Luo [43] revealed that because understanding customers' needs more exactly, and hence analyzing and managing them effectively, are critical to successfully penetrating international markets, entrepreneurial orientation should positively influence international performance. Based on 200 Italian SMEs, Zuccehella [44] examined the determinants of internationalization, arguing that technological capability, marketing capability, and network capability were critical factors in promoting internationalization. Besides this, he found that by interacting with the entrepreneurial orientation, these capabilities play an essential role when entering new global markets and improving international performance. In other words, internationalization can be achieved by the interaction between entrepreneurial orientation and organizational capabilities (e.g., network capability) [44]. Investigating the determinants of internationalization, Brouthers et al. [42] found that organizational capabilities and entrepreneurial orientation lead to improve international performance. Lastly, the network capability helps exporting SMEs reduce transaction costs and make it easy to access important resources such as capital and information [45]. In rapidly changing environments and competitive business environments, SMEs with insufficient resources must plan to enter into new international markets by establishing a network and utilizing it $[46,47]$. In sum, prior studies on entrepreneurial orientation have focused on the individual level rather than the organizational level, proposing the entrepreneurial orientation as a predisposing factor. However, as discussed in the above literature review, entrepreneurial orientation is not limited to the individual level of the CEO. This is comprehensively presented in the whole process of business management activities. Consequently, not only is entrepreneurial orientation a precedent factor, but it also influences organizational capabilities and internationalization both directly and indirectly. Therefore, this study would like to confirm whether entrepreneurial orientation can function as an antecedent of internationalization as well as improving international performance by interacting with network capability, one of the firm's competencies. Based on prior studies, we developed the following hypotheses.

Hypothesis 2. Network capability moderates the relationship between international entrepreneurial orientation and international performance.

Hypothesis 2-1. Network capability moderates the relationship between innovativeness and international performance.

Hypothesis 2-2. Network capability moderates the relationship between proactiveness and international performance.

Hypothesis 2-3. Network capability moderates the relationship between risk-taking and international performance.

Based on the literature discussed above, this study proposes the research model shown in Figure 1. 


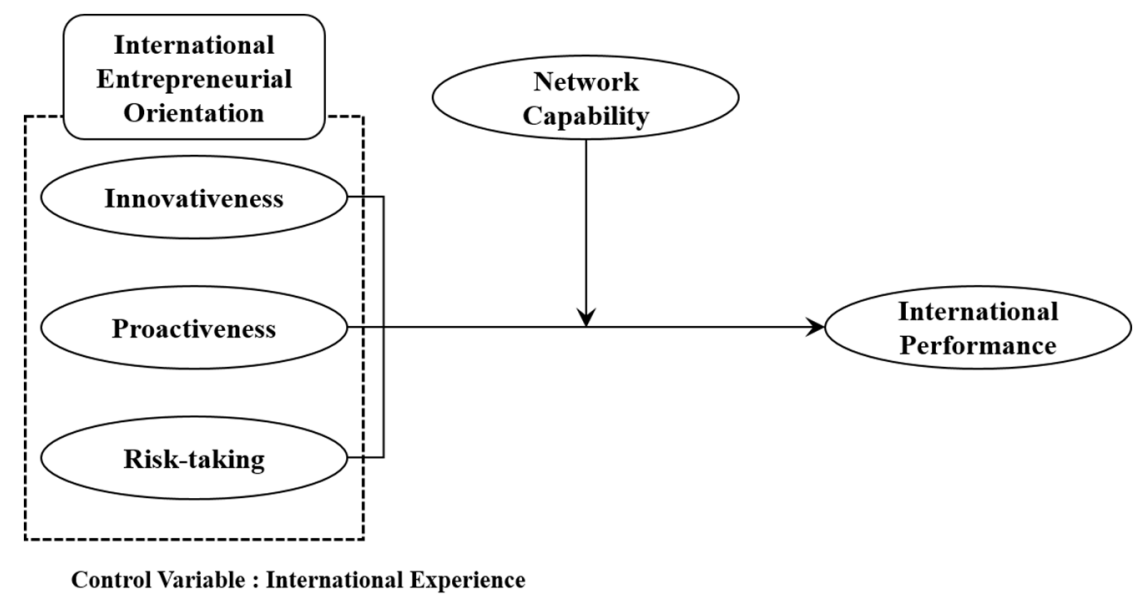

Figure 1. Research model.

\section{Methodology}

\subsection{Sample and Data Collection}

This study focuses on small and medium-sized exporters. Following Nummela et al. [48], this study utilized multiple sources, such as email, websites, and addresses, in order to sort a research sample in which there was no official data that can confirm the sample. To select the proper exporting SMEs, we used various database sources (e.g., the Korea International Trade Association (KITA) and the Small and Medium Business Administration (SMBA)). First of all, we asked the SMBA to provide a list of SMEs. Based on these data, we classified 1214 SMEs suitable for this study. Next, we sent the data to the KITA, which recommended 527 exporting SMEs appropriate for our research aims after identifying whether these SMEs have experience entering into a global market. We verified whether the recommended exporting SMEs are suitable for this study or not by visiting the SMEs' websites, and were able to classify the final 500 exporting SMEs. Finally, in order to check whether the company continued to carry out exporting activities, we visited the websites again two weeks before beginning the survey. Using this procedure, the final 500 exporting SMEs were selected for the survey. To improve the response rate [49], this study combined an online survey with an offline survey.

We distributed 350 offline questionnaires to the exporters confirmed by the above procedure in December 2016. We then sent online questionnaires to another 150 exporters after four weeks. In a further effort to improve the response rate, we sent a reminder email, asking the potential respondents to participate in our survey, as well as contacting the CEOs or managing directors in person because they can represent their companies' attitudes and opinions. As a result, we collected 362 questionnaires (response rate: $72.4 \%$ ). Among these questionnaires, 11 questionnaires could not be used, as they had not been completely answered. Ultimately, the study sample was composed of a total of 334 questionnaires (Please refer to Appendix A). Table 1 presents the key characteristics of the sample, including the respondents' gender and position, the number of employees, and the duration of the export activity. In particular, as the majority of respondents $(85.5 \%)$ had positions higher than that of director, we judged that they represent the characteristics of their firms thoroughly. 
Table 1. Sample characteristics.

\begin{tabular}{lll}
\hline Variables & Number & Percentage \\
\hline Gender & & \\
Male & 231 & 70.7 \\
Female & 103 & 29.3 \\
\hline Position & & \\
CEO & 184 & 52.4 \\
Director & 116 & 33.1 \\
$\quad$ Senior Manager & 51 & 14.5 \\
\hline Number of Employees & & \\
1-49 & 226 & 64.4 \\
$50-99$ & 63 & 17.9 \\
100-149 & 25 & 7.1 \\
150-199 & 35 & 10.0 \\
200-299 & 2 & 0.6 \\
\hline Duration of Export Activity & & \\
Under 3 years & 95 & 27.1 \\
3 to under 5 years & 50 & 14.2 \\
5 to under 7 years & 78 & 22.2 \\
7 to under 9 years & 85 & 24.2 \\
More than 9 years & 43 & 12.3 \\
\hline
\end{tabular}

\subsection{Variables and Measures}

International Entrepreneurial Orientation. This study defined international entrepreneurial orientation as 'entrepreneurial activities in more than two countries', 'a CEO's intention to penetrate into global markets', and 'a CEO's innovative, proactive, and risk-taking tendency to enter into global markets and hence to create value', based on Wright and Ricks [50] and McDougall et al. [6]. In other words, this study defines an international entrepreneurial orientation as 'a CEO's innovativeness, proactiveness, and risk-taking, who seeks internationalization.' To measure entrepreneurial orientation, this study deducted twelve items from the studies of Wright and Ricks [22] and McDougall et al. [6], and then revised the items according to the research purpose for ourselves. The items were measured by the five-point Likert-type scale ( 1 = strongly disagree; 5 = strongly agree).

Network Capability. As a variable that can moderate the relationship between entrepreneurial orientation and international performance, network capability can be defined as the strength of the network ties that help organizations such as technoparks to achieve their goals and improve international performance. All of the indicators were measured by using a five-point Likert-type scale ( 1 = strongly disagree; 5 = strongly agree), drawn from Andersson et al. [51] and Choi et al. [52]

International Performance. In order to measure international performance, four indicators, namely export sales, international assets, number of international markets, and number of international branches, were employed. All of these items were derived from the studies by Bloodgood [53] and Kuivalainen et al. [54], and measured using a five-point Likert-type scale (1 = strongly disagree; $5=$ strongly agree).

Control Variable. To show more clearly the empirical relationships, this study used a control variable. The CEOs' international experience was operationalized by their interaction with other organizations in order to enter into international markets [55]. This variable considers the intensity of the internationalization.

\subsection{Assessing Common Method Bias and Non-Response Bias}

Even though we had collected questionnaires at regular intervals according to the common method bias, this bias cannot be removed perfectly as all items in the questionnaire were measured using the same method, i.e., survey [56]. Consequently, to assess the likelihood of common method 
bias, a confirmatory factor analysis (CFA) was performed. The results were as follows: $\chi^{2}=5642.284$ $(\mathrm{df}=298, p=0.000), \chi^{2} / \mathrm{df}=18.93, \mathrm{GFI}=0.346, \mathrm{AGFI}=0.283, \mathrm{NFI}=0.511, \mathrm{TLI}=0.388, \mathrm{CFI}=0.421$, $\mathrm{RMR}=0.197$, and RMSEA $=0.244$. These results show that there was no statistical significance, that is, it had an extremely poor model fit. Therefore, we concluded that the study was unlikely to be affected by common method bias. According to Armstrong and Overton [57], we measured the likelihood of non-response bias using a $t$-test. We divided all of the responses between the early responses (within four weeks of the mailing) and the later responses (more than four weeks after the mailing) and compared them with regard to key variables such as internationalization and entrepreneurial orientation (i.e., innovativeness, proactiveness, and risk-taking), network capability, and international performance. As a result of analyzing the results of the $t$-test, innovativeness $(p=0.447)$, proactiveness $(p=0.534)$, risk-taking $(p=0.492)$, network capability $(p=0.611)$, and international performance $(p=0.451)$, we found that there were no significant differences between the two groups. Thus, we could conclude that non-response bias was not a critical issue in this study.

\section{Analysis and Results}

\subsection{Measurement Model Results}

In Table 1, we verified the measurement model in order to verify the reliability and validity of the variables used in this study. To evaluate the measurement model, a CFA, confirmatory factor analysis, was employed, which was comprised of six constructs, using IBM AMOS 21.0 (New York, NY, USA). As a result of the CFA, the chi-squared $\left(\chi^{2}\right)$ value did not indicate a high level of statistical significance $\left(\chi^{2}=1357.42\right.$, degrees of freedom $(\mathrm{df})=443, \chi^{2} / \mathrm{df}=3.064$; Table 2$)$. However, this index tends to be biased against large samples. Therefore, even when the model is sound [58,59], it is very difficult to have a proper $\chi^{2}$ value so that $\chi^{2}$ is highly sensitive to sample size. To overcome this limitation, we considered several other indices, including the root-mean-squared residual (RMR), normed fit index (NFI), comparative fit index (CFI), Tucker-Lewis index (TLI), incremental index of fit (IFI), and root-mean-squared error of approximation (RMSEA). These tests produced the following results: the RMR was 0.053; the GFI was 0.888; the AGFI was 0.868; the NFI was 0.911; the CFI was 0.972; the TLI was 0.913; the IFI was 0.916; and the RMSEA was 0.055 .

Table 2. Measurement model results.

\begin{tabular}{|c|c|c|c|c|c|c|c|c|}
\hline \multirow[t]{2}{*}{ Scale $^{\mathrm{i}}$} & \multirow[t]{2}{*}{ Mean } & \multirow[t]{2}{*}{ S.D. } & \multicolumn{6}{|c|}{ Cross-Construct Correlations } \\
\hline & & & (1) & (2) & (3) & (4) & (5) & (6) \\
\hline (1) & 2.7350 & 1.40043 & 1 & & & & & \\
\hline (2) & 2.3312 & 1.00615 & 0.035 & 1 & & & & \\
\hline (3) & 2.6979 & 0.91578 & -0.83 & $0.335^{* *}$ & 1 & & & \\
\hline (4) & 3.3202 & 0.91727 & -0.100 & $0.455^{* *}$ & $0.615^{* *}$ & 1 & & \\
\hline (5) & 2.4303 & 0.90195 & 0.022 & $0.641^{* *}$ & $0.514^{* *}$ & $0.627^{* *}$ & 1 & \\
\hline (6) & 3.1508 & 1.07437 & 0.219 ** & $0.523^{* *}$ & $0.262 * *$ & $0.309^{* *}$ & $0.513^{* *}$ & 1 \\
\hline \multicolumn{3}{|c|}{ Cronbach's $\alpha$} & & 0.970 & 0.811 & 0.864 & 0.897 & 0.953 \\
\hline \multicolumn{3}{|c|}{ Constructs Reliability } & & 0.918 & 0.861 & 0.857 & 0.892 & 0.910 \\
\hline \multicolumn{3}{|c|}{ AVE } & & 0.736 & 0.645 & 0.545 & 0.623 & 0.671 \\
\hline \multicolumn{3}{|c|}{ Goodness-of-fit statics } & \multicolumn{6}{|c|}{$\begin{array}{c}\chi^{2}=1357.42(\mathrm{df}=443), \chi^{2} / \mathrm{df}=3.064, \mathrm{RMR}=0.053, \mathrm{GFI}=0.888, \mathrm{AGFI}=0.868, \\
\mathrm{NFI}=0.911, \mathrm{CFI}=0.972, \mathrm{TLI}=0.913, \mathrm{IFI}=0.916, \mathrm{RMSEA}=0.055\end{array}$} \\
\hline
\end{tabular}

** Significant at $p<0.05 .{ }^{i}$ : (1) International Experience; (2) Innovativeness; (3) Risk-taking; (4) Proactiveness; (5) Network Capability; (6) International Performance.

With the recommended levels for these fit indices, we could assume that the measurement model was not perfect, but it could be acceptable, based on considering a relatively large number of observed indicators for the constructs. The reliability of all of the constructs used was assessed using Cronbach's alpha $(\alpha)$. Nunnally [60] recommended that Cronbach's $\alpha$ values greater than 0.7 are acceptable. The Cronbach's $\alpha$ values of all of the constructs in this study ranged from 0.811 to 0.970 . Moreover, the construct reliability of each scale ranged from 0.857 to 0.918 [61]. As shown in Table 2, to estimate the 
convergent validity of all the constructs, we calculated the average variance extracted (AVE). In general, an AVE value greater than 0.5 indicates that a measurement model is valid. The AVE values of all the variables in this study were greater than 0.545 , indicating that this measurement model had satisfactory convergent validity [57]. We also assessed the discriminant validity of the study using a cross-construct correlation estimate. The results indicated that none of the two-standard-error confidence intervals (i.e., 95\%) included the value of one [62], showing that this study had satisfactory discriminant validity. In addition, Brown [63] suggests that the correlations between constructs of 0.85 or above indicate poor discriminant validity; however, there is no constructs of 0.85 or above in the study, so we can note that this measurement model had satisfactory discriminant validity.

\subsection{Hypothesis Testing}

\subsubsection{Hypothesis 1}

The hypotheses were assessed by interpreting the standardized coefficients in Model 1, as shown in Table 3. We first determined whether the entrepreneurial orientation significantly affected international performance. International entrepreneurial orientation had a significant effect on international performance. In more detail, innovativeness, risk-taking, and proactiveness had significant positive $(+)$ effects on international performance. These results indicate that to improve international performance, firms have to enhance their innovativeness, risk-taking, and proactiveness. Our findings demonstrate that the above variables can act as determinants of international performance. In summary, Hypothesis 1 (1-1, 1-2, 1-3) was supported

Table 3. Regression analysis results.

\begin{tabular}{|c|c|c|c|}
\hline & \multicolumn{3}{|c|}{ Dependent Variable } \\
\hline & \multicolumn{3}{|c|}{ International Performance } \\
\hline & Model 1 & Model 2 & Model 3 \\
\hline \multicolumn{4}{|l|}{ Predictors } \\
\hline International Experience & $0.018 *$ & $0.044 *$ & 0.144 \\
\hline Innovativeness & $0.247^{* * *}$ & $0.151 * * *$ & $0.427 * * *$ \\
\hline Proactiveness & 0.094 * & $0.061 *$ & $0.335 * *$ \\
\hline Risk-taking & $0.567^{* * *}$ & $0.365^{* * *}$ & $0.509 * * *$ \\
\hline \multicolumn{4}{|l|}{ Moderator } \\
\hline Network Capability & & $0.443^{* * *}$ & $0.201 *$ \\
\hline \multicolumn{4}{|l|}{ Interactions } \\
\hline International Experience * Network Capability & & & $1.311 *$ \\
\hline Innovativeness * Network Capability & & & $0.737^{* * *}$ \\
\hline Proactiveness * Network Capability & & & $0.351 * *$ \\
\hline Risk-taking ${ }^{*}$ Network Capability & & & $0.459 * *$ \\
\hline$R^{2}$ & $0.422^{* * *}$ & $0.556^{* * *}$ & $0.572 * * *$ \\
\hline$\Delta R^{2}$ & - & $0.134^{* * *}$ & 0.017 ** \\
\hline$F$ & $60.021^{* * *}$ & $81.983^{* * *}$ & $48.158^{* * *}$ \\
\hline
\end{tabular}

${ }^{*}$ Significant at $p<0.05,{ }^{* *}$ Significant at $p<0.01,{ }^{* * *}$ Significant at $p<0.001$.

\subsubsection{Hypothesis 2}

Hierarchical regression was used to examine our hypotheses. To avoid multicollinearity between the predictors and the interaction items and to enhance the interpretation of the main effects, we centered all variables involved in the interactions [64]. The independent variables (e.g., innovativeness, risk-taking, and proactiveness) were entered into model 1, followed by entering the moderating variable (i.e., network capability) into model 2 (see Table 3 for details). As model 3 (in Table 3) indicated that, among the interactions between the determinants of international performance (e.g., innovativeness, risk-taking, and proactiveness) and the network capability, an interaction between innovativeness and network capability $(\beta=0.737, p<0.001)$, an interaction 
between proactiveness and network capability $(\beta=0.351, p<0.05)$, and an interaction between risk-taking and network capability $(\beta=0.459, p<0.05)$ were significantly and positively associated with international performance, as well as explaining a significant amount of variance in the international performance $\left(\Delta R^{2}=0.017, p<0.05\right)$. This study shows that network capabilities can moderate the relationships between the determinants and the international performance. In summary, hypothesis 2 $(2-1,2-2,2-3)$ was supported. Finally, we can confirm that there was a significant relationship between network capability and international performance. This implies that network capability can act as a determinant of international performance.

\section{Conclusions}

\subsection{Summary and Implications}

In order to help SMEs to improve their international performance, this study developed a research model taking into account international entrepreneurial orientation, composed of innovativeness, risk-taking, proactiveness, and network capability as significant variables regarding successful internationalization. In addition, it sought to empirically test some hypotheses based on the model. In summary, international entrepreneurial orientation had a significant effect on international performance. This result supports the argument in Brouthers et al. [42] that entrepreneurial orientation has a significant or meaningful relationship with international performance. Network capability moderates the relationship between international entrepreneurial orientation and international performance. This supports Zhang et al. [65] and Parida et al.'s [66] results. In other words, international entrepreneurial orientation can play a significant role in improving international performance through network capability. Finally, it found that network capability can act as a determinant of international performance.

There are some implications of this study. Firstly, this study considered international entrepreneurial orientation as an important determinant of international performance, as well as suggesting three constructs, namely the innovativeness, proactiveness, and level of risk-taking of the behavior. In general, the above three have been employed as constructs of entrepreneurship or entrepreneurial orientation; however, the above three constructs can also be employed as constructs of international entrepreneurial orientation [67]. This study confirmed this argument empirically. Thus, this study implies that CEOs should pay more attention to network capability in order to improve their international performance. In more detail, the findings of this study highlight the notion that firms are more likely to improve their international performance when they have a stronger and greater network capability. In particular, considering limitations such as insufficient resources, SMEs have to establish and utilize useful networks with external stakeholders. This study complements the growth limits of the Schumpeterian dynamics of open innovation by suggesting the importance of entrepreneurial orientation in improving organizational competitiveness and international performance. In addition, we propose the importance of setting up global standards to conquer the growth limits of capitalism. Finally, by analyzing the roles of networks in open innovation [68], it was found that entrepreneurs in South Korean tech-based SMEs improve their performance and competitiveness by reinforcing their network capabilities.

\subsection{Limitations and Avenues for Future Research}

Although this study makes several contributions to the literature on internationalization, there are some limitations to the study. First, although this study considers various variables, there may be more significant variables regarding international networks, such as technological and environmental factors. For example, Oviatt and McDougall [2] noted that a stronger technological capability or environmental factors such as dynamics can play an essential role in accelerating internationalization. Therefore, both technological and the environmental factors may act as determinants of successful internationalization. When looking for other major factors related to internationalization, future studies should consider 
technological or environmental factors along with our variables. Our independent variable is only entrepreneurial orientation. Consequently, we would like to propose that future studies should designate various variables such as the characteristics of the entrepreneurs. This study established perceived international performance as a dependent variable. Even though perception-based subjective performance is significantly correlated with objective performance, it is better to take into account both subjective and objective performance. Thus, we hope that future studies will combine objective performance, such as actual financial data, with subjective performance such as organizational effectiveness. In addition, it is difficult to generalize our findings because they were only focused on firms in South Korea. Accordingly, it is necessary to carry out a comparative study between two or more countries in order to increase the generalizability.

Author Contributions: J.Y. is from Dongguk University-Gyeongju, South Korea. K.K.K. (Co-corresponding author) is from Gumi University, South Korea. A.T.D. (The Main Corresponding author) is from Yeungnam University, South Korea. They designed the research conceptual model, collected the survey data, and interpreted the survey results together.

Acknowledgments: This work was supported by the Dongguk University Research Fund of 2017.

Conflicts of Interest: The authors declare no conflict of interest.

\section{Appendix}

Table A1. Measurement items (questionnaire).

\begin{tabular}{|c|c|c|}
\hline Variables & Items & $\begin{array}{l}\text { Cronbach } \\
\text { Alpha }\end{array}$ \\
\hline \multirow{4}{*}{ Innovativeness } & My organization or CEO tends to think of new idea to solve a problem for successful internationalization. & 0.795 \\
\hline & My organisation or CEO accepts organizational members' new ideas for successful internationalization. & 0.799 \\
\hline & $\begin{array}{l}\text { My organisation or CEO encourages organizational members to change something for } \\
\text { successful internationalization. }\end{array}$ & 0.845 \\
\hline & $\begin{array}{c}\text { My organisation or CEO encourages organizational members to share change or innovation for } \\
\text { successful internationalization. }\end{array}$ & 0.712 \\
\hline \multirow{4}{*}{ Proactiveness } & $\begin{array}{c}\text { My organisation or CEO encourages organizational members to do their best to hold a dominant position } \\
\text { in the international market. }\end{array}$ & 0.791 \\
\hline & $\begin{array}{c}\text { My organisation or CEO tries to introduce various methods to hold a dominant position in the } \\
\text { international market. }\end{array}$ & 0.711 \\
\hline & $\begin{array}{l}\text { My organisation or CEO encourages organizational members to carry out their jobs to hold a dominant } \\
\text { position in the international market. }\end{array}$ & 0.702 \\
\hline & My organisation or CEO is more proactive than international rivals. & 0.735 \\
\hline \multirow{4}{*}{ Risk-taking } & My organisation or CEO prefers risk to stability to improve international performance. & 0.812 \\
\hline & My organisation or CEO would like to carry out risky projects to improve international performance. & 0.791 \\
\hline & My organisation or CEO would like to support risky R\&D to improve international performance. & 0.884 \\
\hline & My organisation or CEO prefers international growth to stability. & 0.831 \\
\hline \multirow{5}{*}{$\begin{array}{l}\text { Network } \\
\text { Capability }\end{array}$} & Our organization forms strong and close relationships with potential international partners. & 0.912 \\
\hline & Our organization communicates frequently with international partners. & 0.889 \\
\hline & $\begin{array}{c}\text { Our organization coordinates activities for strong and close relationships with potential international } \\
\text { partners effectively and positively. }\end{array}$ & 0.878 \\
\hline & The international network between our organization and international partners is well embedded. & 0.862 \\
\hline & Our international partners trust us. & 0.799 \\
\hline \multirow{4}{*}{$\begin{array}{l}\text { International } \\
\text { Performance }\end{array}$} & Export sales have been improving. & 0.787 \\
\hline & The number of international markets has been increasing. & 0.812 \\
\hline & International assets have been improving. & 0.912 \\
\hline & The number of international branches has been increasing. & 0.812 \\
\hline
\end{tabular}

\section{References}

1. Rutashobya, L.; Jaensson, J.E. Small firms' internationalization for development in Tanzania: Exploring the network phenomenon. Int. J. Soc. Econ. 2004, 31, 159-172. [CrossRef]

2. Oviatt, M.B.; McDougall, P.P. Defining international entrepreneurship and modeling the speed of internationalization. Entrep. Theory Pract. 2005, 29, 537-553. [CrossRef]

3. Rhee, J.; Yang, H. Relationships among International Entrepreneurship, Core Competence, and Internationalization. Korean J. Bus. Adm. 2011, 24, 3247-3271.

4. Cavusgil, S.T.; Knight, G. Trrhe born global firm: An entrepreneurial and capabilities perspective on early and rapid internationalization. J. Int. Bus. Stud. 2015, 46, 3-16. [CrossRef] 
5. Lu, J.W.; Beamish, P.W. The Internationalization and Performance of SMEs. Strateg. Manag. J. 2001, 22, 565-586. [CrossRef]

6. McDougall, P.P.; Oviatt, B.M.; Shrader, R.C. A comparison of international and domestic new ventures. J. Int. Entrep. 2003, 1, 59-82. [CrossRef]

7. Weerawardena, J.; Mort, G.S.; Liesch, P.W.; Knight, G. Conceptualizing accelerated internationalization in the born global firm: A dynamic capabilities perspective. J. World Bus. 2007, 42, 294-306. [CrossRef]

8. Moen, $\varnothing$. The born globals: A new generation of small european exporters. Int. Mark. Rev. 2002, 19, $156-175$. [CrossRef]

9. Lee, D.-H.; Park, J.-H. Changes in the antecedents of Korean firms' internationalization: Pre and Post the 2008 global economic crisis. Int. Bus. Res. 2017, 28, 1-44. [CrossRef]

10. Kwon, Y. A Comparison Case Study on Early Internationalization and Internationalization Process of Semiconductor Companies: Focused on Semiconductor Company of Taiwan, U.S., Korea and Japan. J. Prof. Manag. 2015, 18, 37-64.

11. Rhee, J.; Park, T. Born global: Effects of international orientation and network on international intensity. Korean Ventur. Manag. Rev. 2009, 12, 1-26.

12. Jun, Y.; Yoon, D. An Exploratory Explanation of the Internationalization Process of the Korean Consumer Electronics Industry. Korea Bus. Rev. 1998, 27, 541-561.

13. Jung, J. Patterns of Internationalization Activities and Firm's Performance of Korean Manufacturing Ventures. J. Small Bus. Innov. 2002, 5, 61-82.

14. Ban, H. Internationalization, Corporate Governance Structures, and Investment Activities. Korean J. Bus. Adm. 2010, 23, 3401-3425.

15. Rialp, A.; Rialp, J.; Knight, G. The phenomenon of early internationalizing firms: What do we know after a decade (1993-2003) of scientific inquiry? Int. Bus. Rev. 2005, 14, 147-166. [CrossRef]

16. Young, S. What do researchers know about the global business environment? Int. Mark. Rev. 2000, 18, 120-129. [CrossRef]

17. Forsgren, M. The Concept of Learning in the Uppsala Internationalization Process Model: A Critical Review. In Knowledge, Networks and Power; Palgrave Macmillan: London, UK, 2015; pp. 88-110.

18. Galende, J.; Fuente, J.M. Internal factors determining a firm's innovative behavior. Res. Policy 2003, 32, 715-736. [CrossRef]

19. Panagariya, A. E-Commerrce, WTO, and developing countries. World Econ. 2000, 23, 959-978. [CrossRef]

20. Hsu, C.L.; Wang, C.H. Forecast the output of integrated circuit industry using a Grey Model improved by the Bayesian analysis. Technol. Forecast. Soc. Chang. 2007, 74, 843-853. [CrossRef]

21. Chandra, Y.; Styles, C.; Wilkinson, I.F. Opportunity portfolio: Moving beyond single opportunity explanations in international entrepreneurship research. Asia Pac. J. Manag. 2015, 32, 199-228. [CrossRef]

22. Teece, D.J. Explicating dynamic capabilities: The nature and micro foundations of (Sustainable) enterprise performance. Strateg. Manag. J. 2007, 28, 1319-1350. [CrossRef]

23. Knight, G.A.; Cavusgil, S.T. Innovation, organizational capabilities, and the born-global firm. J. Int. Bus. Stud. 2004, 35, 124-141. [CrossRef]

24. Kang, T.; Han, Y. An Empirical Study on the Determinants of Internationalization Process of Korean Manufacturing Firms. Korea Bus. Rev. 2007, 36, 91-112.

25. Hitt, A.M.; Ireland, R.D. Corporate distinctive competence and performance: Effects of perceived environmental uncertainty, size, and technology. Decis. Sci. 1984, 15, 324-349. [CrossRef]

26. Zou, H.; Liu, X.; Ghauri, P. Technology capability and the internationalization of new ventures. Organ. Mark. Emerg. Econ. 2010, 1, 100-119.

27. Xu, H.; Carter, L.L.; Taute, H.A.; Dishman, P. Managers' Perceived Risk, Experiential Knowledge, Marketing Capability and International Performance: A Study of Chinese International Enterprises. J. Mark. Dev. Compet. 2016, 10, 53-65.

28. Knight, G.A. Entrepreneurship and marketing strategy: The SME under globalization. J. Int. Mark. 2000, 8, 12-32. [CrossRef]

29. Hills, E.G.; LaForge, R.W. Marketing and entrepreneurship: The state of the art. In The State of the Art of Entrepreneurship; Sexton, D.L., Kasorda, J.D., Eds.; PWS-Kent Publishing Company: Boston, MA, USA, 1992; pp. 164-190. 
30. Yoon, J.; Kim, D.-S. Empirical relationships among technological characteristics, global orientation, and internationalisation of South Korean New Ventures. Sustainability 2016, 8, 1254. [CrossRef]

31. Huggins, R.; Thompson, P. Entrepreneurship, innovation and regional growth: A network theory. Small Bus. Econ. 2015, 45, 103-128. [CrossRef]

32. Lee, C.; Lee, L.; Pennings, J.M. Internal capabilities, external networks, and performance: A study on technology-based ventures. Strateg. Manag. J. 2001, 22, 615-640. [CrossRef]

33. Pappas, M.A.; Drigas, A.S.; Papagerasimou, Y.; Dimitriou, H.; Katsanou, N.; Papakonstantinou, S.; Karabatzaki, Z. Female entrepreneurship and employability in the digital era: The case of Greece. J. Open Innov. Technol. Mark. Complex. 2018, 4, 1. [CrossRef]

34. Jung, D.; Yang, J. The Effects of Core Competence and Networking on Firm Performance-Comparative study between Korea and China SMEs. Korean J. Found. 2008, 3, 43-69.

35. Zahra, S.A.; Ireland, R.D.; Hitt, M.A. International expansion by new venture firms: International diversity, mode of market entry, technological learning and performance. Acad. Manag. J. 2000, 43, 925-950.

36. Yiu, D.W.; Lau, C.-M.; Bruton, G.D. International venturing by emerging economy firms: The effect of firm capabilities, home country networks, and corporate entrepreneurship. J. Int. Bus. Stud. 2007, 38, 519-540. [CrossRef]

37. Porter, M.E. Competitive Advantage; Free Press: New York, NY, USA, 1985.

38. Florida, R. The globalization of R\&D: Results of a survey of foreign-affiliated R\&D laboratories in the USA. Res. Policy 1997, 26, 85-103.

39. Zeithaml, P.C.; Zeithaml, V.A. Environmental management: Revising the marketing perspective. J. Mark. 1984, 48, 46-53. [CrossRef]

40. Etemad, H. The promise of a potential theoretical framework in international entrepreneurship: An entrepreneurial orientation-performance relation in internationalized context. J. Int. Entrep. 2015, 13, 89. [CrossRef]

41. McDougall, P.P.; Covin, G.C.; Robinson, R.B., Jr.; Herron, L. The effect of industry growth and strategic breath on new venture performance and strategy content. Strateg. Manag. J. 1994, 15, 537-554. [CrossRef]

42. Brouthers, K.D.; Nakos, G.; Dimitratos, P. SME entrepreneurial orientation, international performance, and the moderating role of strategic alliances. Entrep. Theory Pract. 2015, 39, 1161-1187. [CrossRef]

43. Zhou, L.; Wu, W.; Luo, X. Internationalization and the performance of born-global SMEs: The mediating role of social networks. J. Int. Bus. Stud. 2007, 38, 673-690. [CrossRef]

44. Zucchella, A. Born globals versus gradually internationalizing firms: An analysis based on italian case studies. In Proceedings of the European International Business Academy (EIBA) Annual 28th EIBA Conference, Athens, Greece, 8-10 December 2002.

45. Gulati, R.; Nohria, N.; Zaheer, A. Strategic Networks. Strateg. Manag. J. 2000, 21, 203-215. [CrossRef]

46. Baum, J.A.C.; Calabrese, T.; Silverman, B.S. Don't go it Alone: Alliance network composition and startups' performance in Canadian biotechnology. Strateg. Manag. J. 2000, 21, 267-294. [CrossRef]

47. Lavie, D. Alliance portfolios and firm performance: A study of value creation and appropriation in the U.S. software industry. Strateg. Manag. J. 2007, 28, 1187-1212. [CrossRef]

48. Nummela, N.; Saarenketo, S.; Puumalainen, K. A Global Mindset-A Prerequisite for Successful Internationalization? Can. J. Adm. Sci. 2004, 21, 51-64. [CrossRef]

49. Kaplowitz, M.D.; Hadlock, T.D.; Levine, R. A comparison of Web and mail survey response rates. Public Opin. Q. 2004, 68, 94-101. [CrossRef]

50. Wright, R.W.; Ricks, D.A. Trends in international business research: Twenty-five years later. J. Int. Bus. Stud. 1994, 25, 687-701. [CrossRef]

51. Andersson, J.O.; Helander, T.; Höglund, L.; Shi, P.; Sundman, B. Thermo-Calc \& DICTRA, computational tools for materials science. Calphad 2002, 26, 273-312.

52. Choi, B.; Park, D.; Jeong, S.; Lee, Y. Networks, Competences, and Firm Performance in Ventures. Korean J. Bus. Adm. 2013, 26, 3115-3146.

53. Bloodgood, J.M. Venture adolescence: Internationalization and performance implications of maturation. Int. J. Entrep. Orientat. Res. 2006, 12, 67-85. [CrossRef]

54. Kuivalainen, O.; Sundqvist, S.; Servais, P. Firms' degree of born-globalness, international entrepreneurial orientation and export performance. J. World Bus. 2007, 42, 253-267. [CrossRef] 
55. Carlsson, B. Internationalization of innovation systems: A survey of the literature. Res. Policy 2006, 35, 56-67. [CrossRef]

56. Podsakoff, P.M.; Organ, D.W. Self-reports in organizational research: Problems and prospects. J. Manag. 1986, 12, 531-544. [CrossRef]

57. Armstrong, J.S.; Overton, T.S. Estimating nonresponse bias in mail surveys. J. Mark. Res. 1977, 14, $396-402$. [CrossRef]

58. Bagozzi, R.P.; Yi, Y. On the evaluation of structural equation models. J. Acad. Mark. Sci. 1988, 16, 74-94. [CrossRef]

59. Baumgartner, H.; Bagozzi, R.; Bagozzi, R.P. The evaluation of structural equation models and hypothesis testing. Princ. Mark. Res. 1994, 16, 386-419.

60. Nunnally, J.C. Psychometric Theory, 2 ed.; McGraw-Hill: New York, NY, USA, 1979.

61. Fornell, C.; Larcker, D.F. Structural equation models with unobservable variables and measurement error: Algebra and statistics. J. Mark. Res. 1981, 18, 382-388. [CrossRef]

62. Anderson, J.C.; Gerbing, D.W. Structural equation modeling in practice: A review and recommended two-step approach. Psychol. Bull. 1988, 103, 411. [CrossRef]

63. Brown, T. CFA with Equality Constraints, Multiple Groups, and Mean Structures; Guildford: New York, USA, 2006.

64. Aiken, L.S.; West, S.G.; Reno, R.R. Multiple Regression: Testing and Interpreting Interactions; Sage Publication: London, UK, 1991.

65. Zhang, X.; Ma, X.; Wang, Y.; Li, X.; Huo, D. What drives the internationalization of Chinese SMEs? The joint effects of international entrepreneurship characteristics, network ties, and firm ownership. Int. Bus. Rev. 2016, 25, 522-534. [CrossRef]

66. Parida, V.; Pesämaa, O.; Wincent, J.; Westerberg, M. Network capability, innovativeness, and performance: A multidimensional extension for entrepreneurship. Entrep. Reg. Dev. 2017, 29, 94-115. [CrossRef]

67. Gruber, M.; MacMillan, I.C. Entrepreneurial orientation: A reconceptualization and extension based on identity theory. Strateg. Entrep. J. 2017, 11, 271-286. [CrossRef]

68. Becker, B.A.; Eube, C. Open innovation concept: Integrating universities and business in digital age. J. Open Innov. Technol. Mark. Complex. 2018, 4, 12. [CrossRef] 